\title{
Review of Steven G. Medema's The hesitant hand: taming self-interest in the history of economic ideas. Princeton: Princeton University Press, 2009, 248 pp.
}

\author{
DAVID M. LEVY \\ George Mason University
}

It is high time for a book such as the one Steven Medema has written on the history of the economic discussion of externalities. As long as there has been a discipline of economics, externalities have been central to a class of ongoing debates. Indeed, a critical explanation (justification?) for a wide range of government action has been the argument that the market has "failed" to provide the right incentives when some activity which I undertake has a direct impact on your output. So deep is this literature that the phrase "market failure" will conjure up a series of setpieces. In some circles where those words are spoken another phrase, "government failure", will come to mind. In this oral tradition, there are stylized positions about the role of government advocated by famous names like Arthur Cecil Pigou, Ronald Coase, and James Buchanan. The oral tradition, as we know to our cost, is a very sad substitute for a real historical study of the arguments.

In the larger picture Medema paints, the move from the classical period in which Adam Smith put forward a system of "natural liberty" to modern welfare economics goes through utilitarianism. We see this in a pair of section headings "Henry Sidgwick and the dismantling of the system of natural liberty" (p. 42) and "Utilitarianism, optimism, and the flight from natural liberty" (p. 50). Sidgwick's immense importance as an ethical thinker has overshadowed his importance as an economist, something which Medema is careful to bring out (pp. 42-50). The technical contributions of the Italian school and Knut Wicksteed are considered in helpful detail (pp. 77-100).

Now, let us look at some of the detailed arguments. Although Medema glances at Adam Smith's sources, it is Smith's work itself which gets the book's first serious attention. Medema tells us about Smith's "natural liberty" and the role he laid out for the sovereign (pp. 22-24). But for the "dismantling" argument to work, Medema needs to make the case that Smith is not a utilitarian. Of course, Smith's system is not 
Edgeworth's but the slogan "greatest happiness of the greatest number" conceals a multitude of models of utilitarianism (see Peart and Levy 2005). Indeed, "natural liberty" in Adam Smith's Wealth of nations (WN henceforth) can be trumped by the well-being of the majority cases of what we might call external diseconomies.

To restrain private people, it may be said, from receiving in payment the promissory notes of a banker, for any sum whether great or small, when they themselves are willing to receive them, or to restrain a banker from issuing such notes, when all his neighbors are willing to accept of them, is a manifest violation of that natural liberty which it is the proper business of law not to infringe, but to support. Such regulations may, no doubt, be considered as in some respects a violation of natural liberty. But those exertions of the natural liberty of a few individuals, which might endanger the security of the whole society, are, and ought to be, restrained by the laws of all governments, of the most free as well as of the most despotical. The obligation of building party walls, in order to prevent the communication of fire, is a violation of natural liberty exactly of the same kind with the regulations of the banking trade which are here proposed (WN, II.2.94).

What cannot be trumped is the "just liberty" of employing one's time as one sees fit "without injury to [one's] neighbor".

The property which every man has in his own labour, as it is the original foundation of all other property, so it is the most sacred and inviolable. The patrimony of a poor man lies in the strength and dexterity of his hands; and to hinder him from employing this strength and dexterity in what manner he thinks proper without injury to his neighbor, is a plain violation of this most sacred property. It is a manifest encroachment upon the just liberty both of the workman, and of those who might be disposed to employ him. As it hinders the one from working at what he thinks proper, so it hinders the others from employing whom they think proper. To judge whether he is fit to be employed, may surely be trusted to the discretion of the employers whose interest it so much concerns. The affected anxiety of the law-giver lest they should employ an improper person, is evidently as impertinent as it is oppressive (WN, I.10.67).

This is not just Smith's opinion. He tells us in The theory of moral sentiments (TMS henceforth) that the "no injury" principle comes from the centre of the religion of ordinary people: 
There is no commonly honest man who does not more dread the inward disgrace of such an action, the indelible stain which it would for ever stamp upon his own mind, than the greatest external calamity which, without any fault of his own, could possibly befal him; and who does not inwardly feel the truth of that great stoical maxim, that for one man to deprive another unjustly of any thing, or unjustly to promote his own advantage by the loss or disadvantage of another, is more contrary to nature, than death, than poverty, than pain, than all the misfortunes which can affect him, either in his body, or in his external circumstances (TMS, III.i.48).

This reliance on shared moral judgment is something which we will come back to. A Smithian account of the story which Medema tells might focus on the growing interest in cases in which the natural liberty of individual action does not satisfy the just liberty condition.

Medema's title "hesitant hand" pays tribute to the phrase Pigou uses in 1935 to describe the ongoing discussion of the "invisible hand"- "All are agreed that many times the hand falters in its aim" (p. 68). It will surprise no one who has been following Medema's work that Coase is a central figure in The hesitant hand and the celebrated evening at Aaron Director's house at which Coase persuaded the economists of the University of Chicago that their Pigouvian analysis was wrong takes a star turn. The upshot of the Coasean episode is that we have learned to distrust any assumption of zero transactions costs. There is a puzzle here. Just about the same time that George Stigler was playing with the zero transactions costs "Coase Theorem" (pp. 111, 176) and its avowedly bizarre implications, he was introducing the positive costs of searching for prices to explain observed price dispersion (see Stigler 1961). We know how seriously he and the Nobel committee took that argument! The puzzle of zero transactions costs gets more intriguing if one remembers the line of attack on "new welfare economics" he launched in his Knightian period. New welfare economics cannot be right, he argued, because we would not in fact pay thieves not to steal even though this payment might well satisfy the efficiency criterion, because it would violate our shared moral judgments (Stigler 1943; Levy and Peart 2008). But Stigler's "Coase theorem" would in fact allow consumers to pay monopolists to behave competitively! So counterexample is now theorem?

What may surprise the reader-it certainly surprised this reader-is how neatly Medema rescues Pigou. Medema finds a drastic difference 
between naïve Pigouvian analysis as confidently used in 1950s, which assumed away any cost of using the political process to correct externalities, and what Pigou was arguing in his lectures in the mid1930s, which was anything but naïve (pp. 67-72, 121-24). Medema's research helps put Pigou's much-neglected review of Friedrich A. Hayek's Road to serfdom in context. Pigou took the link between central planning and totalitarianism as a central problem of the era but suggested that Hayek had the causal arrow pointed in the wrong direction. To have a real totalitarianism the state requires central planning (see Pigou 1944). Pigou's rethinking of Hayek's account is if anything less romantic than Hayek's! In Pigou's account we do not fall into totalitarianism in some unintended fashion, as some readings of Hayek suggest; rather, it is planned by those who control the state.

Medema rightly pays a great deal of attention to the late lamented Thomas Jefferson Center at the University of Virginia, co-founded by Warren Nutter and James Buchanan. Not only did Coase pass through the Thomas Jefferson Center on the way to Chicago, but a major line of the economic analysis of the political process was restarted there by Buchanan, Gordon Tullock and their colleagues. If one appeals to the political process to correct market failure, it would be a good idea to know something about its properties. Unhappily, the post-war era in America was a period of ideological conflict in which economic research was a target. The individualist movement in the late 1940s and early 1950s changed economic teaching by destroying the market for Lorie Tarshis's textbook and presenting Paul Samuelson's with a de facto monopoly (Samuelson 1997). Medema offers a dispassionate review of the role of a private foundation and the University administration in destroying one of the most creative research centers of that era (pp. 145-147). It took considerable managerial ability to let Coase, Tullock, and Buchanan walk away from the department.

What was the fight all about? Even if we ignore the first round, simple ideological explanations do not work for the second. Nutter and W. W. Rostow were united across their obvious political divide against the "intellectual establishment" on how to model Soviet growth (see Levy and Peart 2011). Buchanan and John Rawls were separated ideologically but united (at a minimum) by a shared affection for Frank Knight's version of economics in which rules of fair play-shared morals-trump efficiency (see Peart and Levy 2008). 
Some of the fight may have been a simple unintended consequence of Buchanan's and Tullock's insistence that the same model of rational agency that characterized the economics of market activity be carried over to the economics of political activity. Here I note my commitment: it was this Buchanan-Tullock insistence on motivational homogeneity that got us thinking about the larger question of the classics' analytical egalitarianism (Peart and Levy 2005; and 2008). Economic agents of the 1950s and 1960s were supposed to be motivated by material things whereas rewards carried by language such as praise and blame were assumed to be cheap talk and therefore without consequence. The fact that the classical economists embedded their agents in language was offered as a reason not to take their arguments seriously.

Public choice analysis sliced through the literature because, by walking away from our past, neoclassical economists had forgotten how to deal with the sort of commons which democracy creates. The neglect of language-linked rewards does not have a symmetric impact on our ability to model markets and politics. Worry about the commons comes late in Medema's story (pp. 131-139) when the founders of public choice theory in the 1950 s noticed that democratic politics creates a commons. Anthony Downs's (1957) development of rational ignorance and Tullock's (1959) paper on self-interested voting in a fiscal commons are two particularly memorable contributions.

What had been forgotten in that era was the half century of work in British economics after the commons problem exploded with William Godwin's 1790s proposal to replace private property with a system of equality so that the poor could afford marriage. We have been arguing about how to read T. R. Malthus for two centuries without evidence of convergence so let us simply look at how Godwin rephrased Malthus's challenge to the resulting divergence between private and social cost:

It is true, the ill consequences of a numerous family will not come so coarsely home to each man's individual interest, as they do at present. It is true, a man in such a state of society might say, If my children cannot subsist at my expense, let them subsist at the expense of my neighbour (Godwin [1801] 1993, 204).

Is there a clearer statement of the social dilemma of a commons extant?

Any Malthusian then who wished to defend a commons would need to propose something to replace material incentives, just as Godwin 
realized in his first response to Malthus. Of course, here is where J. S. Mill enters when he proposed that public opinion and the rewards of approbation could replace private markets. It speaks well of both of them that Ludwig von Mises singled out Mill's defense of socialism as the one worth considering (see Peart 2009).

Mill does not simply stop there. He offers a most acute analysis of the economics of competitive democracy in a brief discussion of elections in 1865 . The question on the table was whether voting should be transparent or secret. Mill applied Malthus's logic to the great commons of politics. Here, no one has a private material interest to act in accord with what one believes to be the public interest.

That minute benefit is not only too insignificant in amount, but too uncertain, too distant, and too hazy, to have any real effect on his mind. His motive, when it is an honourable one, is the desire to do right. [...] It is possible, indeed, that he or his class may have a private interest acting in the same direction with the public interest, as a man who has speculated for a fall in corn has an interest in a good harvest; and this may determine his conduct. But, in that case, it is the private interest that actuates him, not his share of the public interest (Mill 1865, 1214).

If voting is motivated by our judgment of the public interest, what institution offers the most effective incentives: transparent or secret voting? Mill drew the conclusion that if one's vote were transparent, it would be more influenced by considerations of praise and blame than if it were secret:

Since, then, the real motive which induces a man to vote honestly is, for the most part, not an interested motive in any form, but a social one, the point to be decided is, whether the social feelings connected with an act, and the sense of social duty in performing it, can be expected to be as powerful when the act is done in secret, and he can neither be admired for disinterested, nor blamed for mean and selfish conduct. But this question is answered as soon as stated. When in every other act of a man's life which concerns his duties to others, publicity and criticism ordinarily improve his conduct, it cannot be that voting for a member of Parliament is the single case in which he will act better for being sheltered against all comments (Mill 1865, 1214).

This facility with the incentives in both private and commons perhaps explains why Mill's analysis of externalities is singled out by 
Medema for particular attention (pp. 33-42). Mill, it might be noted, also took the compensation principle as practiced in the Act of Emancipation as a paradigm for legal reform. Indeed, Mill's discussion of the problem of Irish property rights can be seen as an analysis with a laser-like focus on the divergence between private and social benefits (see Peart and Levy 2005).

One episode missing from Medema's account is Buchanan's Knightian criticism of the application of the Arrow impossibility theorem, the subject of Amartya Sen's presidential address (Sen 1995). Here and elsewhere Sen speaks to the connection between public choice and social choice theory.

Let us not close on a gap. Anyone with research interests that concern the correction of market failure by political methods or who wonders whether to trust the oral tradition of economics to get it right should read Medema's book in the near future. We are going to be talking about Medema's book for a very long time.

\section{REFERENCES}

Downs, Anthony. 1957. An economic theory of democracy. New York: Harper \& Row.

Godwin, William. [1801] 1993. Thoughts occasioned by the perusal of Dr. Parr's Spital sermon. In The political and philosophical writings of William Godwin, vol. 2, ed. Mark Philp. London: Pickering \& Chatto Ltd.

Levy, David M., and Sandra J. Peart. 2008. Stigler, George Joseph (1911-1991). The New Palgrave Dictionary of Economics (second edition), eds. Steven N. Durlauf, and Lawrence E. Blume. Palgrave Macmillan.

http://www.dictionaryofeconomics.com/article?id=pde2008_S000262 (accessed 23 Oct. 2011).

Levy, David M., and Sandra J. Peart. 2011. Soviet growth and American textbooks: an endogenous past. Journal of Economic Organization and Behavior, 78 (1-2): 110125.

Mill, John Stuart. [1865] 1986. Romilly's public responsibility and the ballot. In Newspaper Writings, vol. 25 of The collected works of John Stuart Mill, ed. Anne Robson. Toronto: University of Toronto Press.

Peart, Sandra J. 2009. We're all 'persons' now: classical economists and their opponents on marriage, the franchise, and socialism. Journal of History of Economic Thought, 31 (1): 3-20.

Peart, Sandra J., and David M. Levy. 2005. The "vanity of the philosopher": from equality to hierarchy in post-classical economics. Michigan: University of Michigan Press/Ann Arbor.

Peart, Sandra J., and David M. Levy (eds.). 2008. The street porter and the philosopher: conversations on analytical egalitarianism. Michigan: University of Michigan Press/Ann Arbor.

Pigou, Arthur Cecil. 1944. Review of 'The road to serfdom'. The Economic Journal, 54 (214): 217-219. 
Samuelson, Paul A. 1997. Credo of a lucky textbook author. Journal of Economic Perspectives, 11 (2): 153-169.

Sen, Amartya. 1995. Rationality and social choice. American Economic Review, 85 (1): 124.

Smith, Adam. 1790. The theory of moral sentiments (TMS). London: A. Millar. Library of Economics and Liberty [Online]. http://www.econlib.org/library/Smith/smMS.html (accessed 23 Oct. 2011).

Smith, Adam. [1789] 1904. An inquiry into the nature and causes of the wealth of nations (WN), ed. Edwin Cannan. London: Methuen \& Co., Ltd. Library of Economics and Liberty [Online].

http://www.econlib.org/library/Smith/smWN.html (accessed 23 Oct. 2011).

Stigler, George J. 1943. The new welfare economics. American Economic Review, 33 (2): 355-359.

Stigler, George J. 1961. The economics of information. Journal of Political Economy, 69 (3): 213-225.

Tullock, Gordon. 1959. Problems of majority voting. Journal of Political Economy, 67 (6): 571-579.

David M. Levy is professor of economics at the Center for the Study of Public Choice, James M. Buchanan Center for Political Economy, at George Mason University. His research interests include econometrics and the history of economic thought. His most recent book is The street porter and the philosopher (co-edited with Sandra Peart, 2008).

Contact e-mail: <dlevy@gmu.edu> 